\title{
The Growth Impact of Language Standardization: Metcalfe's Law and the Industrial Revolution
}

\author{
Leonard Dudley (Université de Montréal) \\ and Christopher Rauh (University of Cambridge)
}

January 13,2020

\begin{abstract}
During the Industrial Revolution, did population growth stimulate innovation, or did causality run primarily from innovation to growth? Previous research fails to explain why between 1700 and 1850: (i) most innovation originated in three clusters of cities in Britain, northern France, and the USA; (ii) the rate of urbanization in these innovating regions was greater than it was elsewhere; (iii) the most important innovations involved cooperation between co-inventors with different areas of specialization. The key, we suggest, was the existence, for the first time in history, of rapidly expanding networks of people able to write and speak standardized languages. Metcalfe's (2013) Law states that the value of a network grows as the square of the number of its users. We find that the presence in 1700 of a monolingual dictionary describing a language which considerable numbers of people were able to read and speak was significant in determining a city's subsequent innovation. In turn, innovation - especially cooperative innovation - was significant in explaining a city's population growth.
\end{abstract}

\section{The Question}

Does economic growth stimulate innovation or does causality run rather from innovation to growth? Between 1700 and 1850, as mean temperatures in Western Europe rose, its population of doubled. ${ }^{1}$ Simultaneously, there was a virtual explosion of innovation in the West: historians of technology have identified over one hundred important new techniques during this period (see Appendix I). Did these technologies suddenly allow given resources to support a much larger population? Or did more rapid demographic growth provide a greater opportunity for improvements to existing techniques?

\footnotetext{
${ }^{1}$ Estimate based on Maddison (2007, 376).
} 
Previous explanations of economic growth in the West between 1700 and 1850 have generally fallen into one of two groups. A first set of studies has emphasized the impact of innovation on growth; namely, through cultural and institutional forces that encouraged entrepreneurship. North (1981, 1990) stressed the importance of institutions that reinforced the rights of property owners and assured the enforcement of contracts. Similarly, Acemoglu and Robinson $(2012,82)$ pointed to the emergence of "inclusive" political institutions as the keys to Britain's economic success. Whereas Weber (1905/1992) had emphasized religion, Landes (1998, 219) widened the definition of contributing institutions to include Britain's individualistic culture. For Mokyr (2002, 34; 2017, 121), to innovate a society had to have an ideology that favored new ways of practical thinking. McCloskey (2010) asserted that a cultural change leading to the social approval of markets and business explained modern economic growth, while Clark (2009) emphasized the long-term impact of a society's cultural evolution and genetic heritage on economic behavior.

A second group of authors has pointed to the impact of economic growth on the incentive to innovate. In Britain and America, Allen (2009, 105, 173-175) suggested, a unique constellation of factor prices created a demand for the mechanization of manufacturing. With the expansion of Britain's foreign trade, the relative cost of skilled labor rose. Because of the country's abundant energy resources in the form of coal and falling water, it became profitable to develop new technologies that replaced labor with powered machinery. However, in Asia, Pomeranz (2000, 6263) argued, abundant labor and scarce alternative power sources, precluded the application of such energy-using technologies. More recently, Desmet, Greif and Parente (2019) asserted that not factor prices but the degree of intercity competition capable of offsetting guild monopolies determined the rate of innovation. Such spatial competition was more intense in England than in China after 1700 because of more rapid English urban growth.

However, some additional factor would seem necessary to explain why the first Industrial Revolution was so tightly constrained geographically, so sudden, and to date at least, permanent. A detailed examination of more than 100 of the key innovations between 1700 and 1850 reveals three characteristics that have not been adequately explored previously. First, as we show in the next section, roughly 90 percent of these new technologies were developed in three clusters of cities in Britain, its American offshoot and northern France - regions that had contributed few innovations over the previous two centuries (Daumas, 1980). Second, the cities and towns of these regions grew considerably more rapidly than their counterparts elsewhere in the West, despite the fact that other 
than London and Paris, neither Britain nor France had previously experienced very large urban centers. Third, the most important of these new technologies involved prolonged cooperation between two or more individuals - a trend that has continued well beyond 1850 (see, for example, Vuola and Hameri, 2006) - although there had been very few previous documented examples of successful joint innovation in the West $^{2}$.

One is tempted to ask what might have changed in Britain, its American colonies and northern France - but not elsewhere - during the decades prior to 1700. One learns that in 1658, Edward Phillips authored the first privately published monolingual dictionary of the English language. Over the following four decades, The New World of English Words would be published in four further editions (Jackson, 2002, 36). Some two decades after Phillips, in 1680, Pierre Richelet published an analogous document for the French language that was smuggled into France from Geneva. These two dictionaries constituted in effect descriptions of how educated people talked and wrote in London and Paris, respectively, at that time. It would take another century or more before equivalent dictionaries were published in most other European languages (see Appendix II).

How might standardizing a language facilitate innovation? In addition to allowing people in general better to understand one another, a standard tongue may have played two other critical roles. First, unlike regional dialects, a standard language tends to be reshaped by what Kloss $(1967,29)$ has called "ausbau"; that is, reshaping for specific purposes, such as education, science, and technology. When two technicians discussed their work, for example, they would generally need to use a standard language because their local dialects lacked the necessary vocabulary (Joseph, 1987, 79). Second, imagine two strangers meeting. Empirical studies have shown that the crucial issue for each person is whether the other can be trusted (Wojciszke et al., 1998; Fiske et al., 2007). Experiments by Lev-Ari and Keysar (2010) indicate that one of the measures people use to evaluate trustworthiness is accent: the stronger one's accent, the less credible one sounds. Moreover, this conclusion applies not only to those using a second language but also to those speaking variants of the same language (Sumner and Samuel, 2009; Sumner, 2015).

These arguments are consistent with recent studies suggesting that the emergence of standardized languages - defined as the accepted use of a variety of speech with a codified written form - may

\footnotetext{
${ }^{2}$ The most famous prior example of joint innovation -- the partnership between Gutenberg and Fust -- had ended up in court, with the latter suing the former for misuse of funds (Rees, 2006, 11).
} 
have played an important role in economic change over the modern period. Dittmar (2011) showed that the diffusion of the printing press was significant in explaining European urban population growth between 1500 and 1800. Sasaki (2017) found that the timing of the acquisition of the printing press explains the great dispersion in the dates of language standardization across the regions of Western Europe. Dudley (2017) provided evidence that the date of publication of a country's first monolingual dictionary helps explain the timing of innovation in cities of the West. Might language standardization, as indicated by the presence of a monolingual dictionary, have been a "mediator" that transmitted the effects of Gutenberg's invention to the industries whose rapid growth characterized the Industrial Revolution?

There is one strong objection that might be raised to a possible causal link between the early English and French dictionaries mentioned above and subsequent economic growth in Britain and France. The data set for Dudley's (2017) study excluded regions of the West in which there were no important innovations; notably, Spain and most of Italy. However, as the next section will show, there had been somewhat earlier monolingual dictionaries published in both of these present-day countries. If standardization was important for innovation, why did the early monolingual Italian and Spanish dictionaries not trigger rapid growth?

The goal of the present exercise is to extend Dudley's (2017) study of language standardization and innovation to cover their impact on economic growth. In the next section, we begin by outlining the main features of innovation and urban growth in the West during the Industrial Revolution. We show that the most important innovations identified by economic historians were concentrated in three clusters of rapidly growing cities. Rates of urban population growth across countries were in turn strongly correlated with innovation rates. To explore why some early monolingual dictionaries failed to trigger rapid innovation and growth, we refer to Metcalfe's (2013) Law, which states that the value of a network increases with the square of the number of its users.

Section 3 then specifies a two-part estimation procedure to explain urban growth. The first part proposes a means of predicting the location of innovation while taking account of the large number of localities with zero contributions. The second part then proposes a means of testing whether the number of innovations so explained can account for observed differences in population growth between cities. 
In Section 4, we estimate the innovation equation, distinguishing between non-cooperative innovations (those with a single inventor) and cooperative innovations (those having two or more inventors). As in Dudley (2017), the data set consists of 117 important innovations and the populations of 251 European and North American cities, at intervals of 50 years between 1700 and 1850. The results of these estimates confirm that language standardization was important as a possible explanation for both types of innovation, but particularly critical for cooperative innovation. This cooperative innovation in turn was one of the principal sources of urban growth during the Industrial Revolution.

It is reasonable to suppose that the ability to speak in a standard tongue facilitated the technical communication and trust that were necessary for successful cooperation. Accordingly, in Section 5, we use the presence of a monolingual usage dictionary in 1700 as an instrument to test the direction of causality between innovation and growth. 


\section{The Geography of Innovation, Urbanization and Language Standardization}

In this section, we begin by describing a set of innovations that historians of technology have identified as being important and identifying the regions in which they were developed. We then compare innovation rates and annual rates of urbanization across the innovating regions. Finally, we note that the key innovations involved cooperation between individuals with different specializations in the states which had standardized languages.

\section{(a) The Innovation Space}

An important dimension of the Industrial Revolution was a series of technological improvements that raised worker productivity. Moser (2005) used patent data from the middle decades of the nineteenth century to measure innovative activity. However, if we are interested in earlier periods, we must recognize that patent data provide neither a reliable measure of innovative efforts nor an indication of their economic impact (MacLeod and Nuvolari, 2016, 82-83). Following Dudley (2017), we have therefore selected a set of innovations between 1700 and 1850, each of which was mentioned by at least two prominent historians of technology. By this criterion, using studies by Donald Cardwell (1991), Maurice Daumas (1979) and his associates, Joel Mokyr (1990) and Akos Paulinyi (1989) and the contributors to the Encyclopedia Britannica, we identify the 117 innovations listed in Appendix I that were particularly significant. The regions in which these innovations were developed constituted what might be called an "innovation space" - an area that accounted for virtually all the world's important innovations over a century and a half. ${ }^{3}$

Let us examine the regions in which these innovations originated. The innovation space contained 251 urban centers with populations over 5,000 in 1700. Yet all the selected innovations were concentrated in the areas surrounding only 30 of these cities, as Figure 1 indicates. It is perhaps not surprising that the two largest cities by far, the national capitals of England and France, with populations of one-half million or more in 1700 , each had ten or more innovations over the following century and a half. However, Birmingham and Manchester, small towns with populations

\footnotetext{
${ }^{3}$ In addition to Great Britain, France, Belgium, the Netherlands, German, Switzerland and Denmark, the European portion of this space is defined to include northern Italy and western Austria. Each innovation was assigned to the closest city that had over 5,000 residents in 1700 .
} 
of well under 10,000 in 1700 , together had more innovations than the two national capitals over the same period.

A closer look at the geography of the North Atlantic as displayed in Figure 1 reveals a remarkable fact. Over 90 percent of the European innovations were generated within two clusters, each roughly 100 miles $(160 \mathrm{~km})$ wide and 400 miles $(640 \mathrm{~km})$ long in Great Britain and France. One of these regions stretched from the Portsmouth to southern Scotland, while the other extended from Le Havre through Paris to Lyon. A similar oval along the northeast coast of the United States, from Boston to Philadelphia, accounted for all the significant innovations outside Europe.

Evidently, during the century and a half after 1700, something was occurring within these clusters of cities that had not yet touched the rest of the world.

\section{(b) Innovation and Urban Growth}

How was this innovation activity related to urban growth? Figure 2 presents the relationship between innovation and urbanization between 1700 and 1850 for the nine present-day European states within our innovation space. As the horizontal axis shows, rates of innovation per capita were highest in Great Britain and the United States. Note also that the innovation rate of France was much higher than that of Germany. Two other countries - Switzerland and Denmark - also had appreciable rates of innovation. However, Austria, Italy, Belgium and the Netherlands had negligible innovation.

A convenient measure of urban growth is the difference between the average annual rate of population growth in cities of more than 5,000 inhabitants and the population growth rate for the present-day country as a whole. We see that this rate of urbanization, measured along the vertical axis in Figure 2, was positive for the three countries with significant numbers of innovations Britain, the USA and France. Switzerland and Germany also had positive rates of urbanization. However, in the remainder of innovation space - Austria, Belgium, Denmark, Italy and the Netherlands - the population of the cities increased less rapidly than that of the countryside and the smaller towns, indicating disurbanization.

The trend line in Figure 2 suggests the presence of a strong positive relationship between innovation and urbanization. In the three countries with clusters of innovating cities the rate of urbanization was positive. However, in the four countries with negligible rates of innovation - Austria, Italy, 
Belgium and the Netherlands - the urban regions increased their population less rapidly than the rural regions. What might the latter states have lacked that was present in Britain, the USA and France?

\section{(c) Cooperation and Language Networks}

The data on innovation and urbanization in Figure 2 suggest the presence of some additional factor that may have been overlooked in previous studies of the Industrial Revolution. It is helpful to disaggregate our sample of 117 notable innovations into two categories, as summarized in Appendix III. A first group comprises 54 technologies that may be termed cooperative innovations (CIs). In each case, the available biographical information permits identification of both a principal and at least one unrelated collaborator who made a significant contribution. From the biographies, one may suggest that had the other individual(s) not participated in the development of these innovations, the technologies would not have been successful. These cooperative innovations tended to be relatively complex, requiring the integration of distinct areas of specialization. The names of the cities in which these cooperative innovations were developed are underlined in Figure 1. All were in Britain, northern France, and the USA.

The second category consists of non-cooperative innovations (NCIs) - those for which only a single inventor may be identified. These inventions tended to be conceptually simpler than the CIs; for example, John Kay's flying shuttle, James Hargreaves's spinning jenny and Edmund Cartwright's wooden power loom. Like the cooperative innovators, however, these independent inventors depended on the trust of their suppliers, employees, and customers. It might be noted that Britain, France, and the United States accounted for 90 percent of these NCIs.

Might this evidence of the clustering of innovative behavior, particularly cooperative innovation, suggest that people within the urban groupings centered in London and Paris had a means of communicating that was missing, at least temporarily, in the rest of the West? The strong demand for the monolingual dictionaries of Edward Phillips (1658) and Pierre Richelet (1680) prior to 1700 indicates the presence in Britain and France of networks of people sharing a common tongue. Note that these were usage dictionaries that reflected the way educated people wrote and spoke in London and Paris, respectively. 
As mentioned in the introduction, there were two monolingual dictionaries published even earlier, but outside what we defined above as the innovation space. The latter were prescriptive dictionaries, providing guidelines for writers in Castilian and Tuscan dialects. One was Sebastián de Covarrubias' El Tesoro de la lengua castellana o Española. Published in 1611, the Tesoro was an etymological dictionary devoted to the origin of words in the Castilian dialect. Intended primarily for specialists who spoke Latin rather than the general reader, it excluded many common words, while even those words included were sometimes spelled differently at different places in the text (Carriazo Ruiz and Mancho Duque, 2003, 222-223). The initial print run was for only 1,000 copies and it was not reprinted for over half a century (Alvar Ezquerra, 2011, 73).

A second early monolingual dictionary was the Accademia della Crusca's Vocabolario of the Florentine dialect. Published in 1612, this document was intended to provide a prescriptive norm to which Italian writers were advised to conform. It was based primarily on the style of the fourteenthcentury Florentine writers, Dante, Petrarch and Boccaccio (Vincent, 1990, 280). From its first appearance, this dictionary was criticized for its archaisms and for its exclusion of common words and technical vocabulary (Polimeni, 2019, 118-119). Not until more than a decade after Italian unification in 1861 was a true "usage" dictionary reflecting the speech of contemporary Florentine residents published (Ibid., 120).

Why might the publication of a monolingual dictionary have stimulated innovation and urban growth in some societies but not in others? Drawing on the contributions of earlier linguists, John Earl Joseph has identified four criteria that help determine the norms of a standardized language: namely, geographic, literary, aristocratic, and democratic. The "tool of standardization" of these norms, he suggests is the dictionary, which codifies of "an ideal, devoid of real existence" (Joseph, 1987, 161). In the cases of interest, it is generally recognized that all four of the dictionaries mentioned in this section satisfy the first three of these criteria: they embody the form of the language considered to be the purest (geographic); they contain the variant used by the best authors (literary), and the dialect used by the highest social classes (aristocratic) ${ }^{4}$.

Consider however, the fourth, democratic, criterion; that is, the demand for standardization. To be conservative, let us assume that in 1700 the literacy rates in London, Paris, Madrid, and Florence

\footnotetext{
${ }^{4}$ Baugh and Cable, 1993, 18.
} 
were identical to those of the regions comprising the corresponding present-day countries in that year. Furthermore, assume that the literate and only the literate in those cities spoke the dialect of the first monolingual dictionaries. In a network of $n$ people, each person can communicate with $n$ 1 others. The total number of possible unidirectional transmissions is therefore $n(n-1)$. Accordingly, it may be seen that the potential value of such a network increases with the square of $n$, a formulation which has become known as Metcalfe's Law. Metcalfe (2013) showed that this relationship accurately predicted the revenue growth of Facebook as the number of its users rose.

The challenges for the Castilian and Tuscan languages in 1700 were twofold. First, the small size of each language's population base, shown in column (2) of Table 1, limited the possible interaction between native speakers and those visiting from other regions. Second, the low literacy rates displayed in column (3) indicate that the education system could play only a limited role in language standardization. As a result, we see in column (5) that the potential values of the language networks of Britain and France in 1700 were at least 150 times greater than those of Italy and Spain. Of course, not all such links would have been be activated, but these results provide a first approximation to the possibility that two people with complementary abilities could come into contact with each other in these societies 5 .

Table 1. Monolingual dictionaries in 1700 as measures of language standardization

\begin{tabular}{|l|c|c|c|c|c|}
\hline Country & $\begin{array}{c}\text { City where } \\
\text { dictionary } \\
\text { published }\end{array}$ & $\begin{array}{c}\text { Population of } \\
\text { city in } 1700\end{array}$ & $\begin{array}{c}\text { Country } \\
\text { literacy rate } \\
\text { in } 1700(\%)\end{array}$ & $\begin{array}{c}\text { Estimated } \\
\text { number of } \\
\text { literate }\end{array}$ & $\begin{array}{c}\text { Square of } \\
\text { number of } \\
\text { literate }\end{array}$ \\
\hline Great Britain & $(1)$ & $(2)$ & $(3)$ & $(4)$ & $(5)$ \\
\hline France & London & 575,000 & 33 & 189,750 & $36.0 \times 10^{9}$ \\
\hline Italy & Paris & 500,000 & 25 & 125,000 & $15.0 \times 10^{9}$ \\
\hline Spain & Florence & 72,000 & 13 & 9,360 & $0.087 \times 10^{9}$ \\
\hline
\end{tabular}

Sources: See "Data Sources" at the end of the text.

Might the early lead of Britain and France in language standardization help explain their precocity in experiencing rapid urban economic growth, as shown in Figure 2? Support for this possibility is suggested by the correlation coefficients displayed in Table 2. Over the three half-centuries between 1700 and 1850 , the number of innovations that a society developed was correlated significantly with language standardization, as measured by whether its residents had a monolingual usage dictionary

\footnotetext{
${ }^{5}$ This networking hypothesis would help to explain the results of Squicciarini and Voigtländer (2015) showing that the density of subscriptions to the mid-18th century Encyclopédie is a strong predictor of city growth after the beginning of French industrialization.
} 
in 1700. The number of innovations was in turn highly correlated with the increase in the city's population in the same period.

Was the standardization of national languages really a necessary condition for potential innovators to be able to communicate with one other? As Mokyr $(2019,170)$ pointed out, by 1600 the widespread use of Latin in Western Europe had permitted a "Republic of Letters" among intellectuals, in which ideas circulated freely across state borders. He asserted that attitudes toward transforming the material environment developed in the seventeenth century were instrumental in preparing the "Industrial Enlightenment" that followed (Ibid., 221). Yet it should be noted that like most of their fellow innovators, neither of the two most prolific partners in the list of Appendix I Matthew Boulton and James Watt - had benefited from a post-secondary education ${ }^{6}$. Few of the other inventors in the table would have been able to communicate fluently in Latin.

It could nevertheless be argued that language standardization was simply one facet of the harmonization of institutions that was possible within a large, centralized organization. In 1600, England and France were both large states ruled by strong governments that had centralized power in their capital cities: London and Paris, with populations of 200,000 and 300,000 respectively, were the megacities of Western Europe ${ }^{7}$. At that time, other cultural regions of Western Europe were divided into small political units characterized by considerable local autonomy. Accordingly, we should include a measure of the degree of centralization prior to the publication of dictionaries in our specifications as a possible confounding factor.

In short, there are three key features of the first Industrial Revolution that the early creation of vernacular language networks in Britain and France could help to explain: first, the clustering of innovation in regions centered in London, Paris, and New York; second, the rapid growth of cities in these regions; and third, the appearance of cooperative innovation almost exclusively in these areas. In the next section, we specify a two-step procedure to test this hypothesis.

\footnotetext{
${ }^{6}$ In grammar school, Greek and Latin had failed to interest Watt (Tann, 2014, 2), while Boulton had left school by age fifteen (Uglow, 2002, 24). Their local dialects, Scots and Midland English, were mutually incomprehensible. However, both men had been educated in standard English thanks to the decision in 1604 of James I, after becoming king of England, to impose the London dialect for a new translation of the Bible to be used by the churches of each of his kingdoms (Nicholson, 2003, 59). ${ }^{6}$

${ }^{7}$ The next largest cities in the innovating area of Western Europe were Milan with 120,000 and Rouen with 70,000 residents in that year.
} 


\section{Modeling Innovation and Economic Growth}

To test the hypothesis that language standardization helps explain the location of innovation and urban growth during the Industrial Revolution, we specify two equations: one for the innovation process and a second for the urban-growth process.

\section{(a) The Innovation Process}

Consider the innovations developed in city $i$. Assume that innovation occurs when an individual from that city combines his or her knowledge with the expertise of someone from another city who speaks the same standardized language. In a given period, let the number of innovations in the city then be expressed as a function of the exponents of its population, $n_{i}$, and whether or not its residents have adopted a standardized language that allows them to communicate with strangers, $s_{i}$.

$$
y_{i}=\exp \left[C+\beta_{1} n_{i}+\beta_{2} s_{i}\right]
$$

This equation expresses the expected number of innovations produced in a given period after the introduction of a standardized language in a form that may be inserted into a Poisson distribution.

The next step is to integrate this approach into a specification that incorporates the institutionalcultural and factor-price approaches used in previous studies. Define the dependent variable as the number of innovations of a given type that occurred in the region surrounding a given city during each half-century between 1700 and 1849. Since such innovations may be considered rare events, we should use an estimation method appropriate for count data. The variance of this variable in our sample (0.182) is considerably greater than the mean (0.065). To allow for this over-dispersion (a greater frequency of zero observations than the Poisson distribution assumes), a negative-binomial specification is appropriate, since it has an extra parameter to adjust the variance separately from the mean.

There is another characteristic of the data to consider. Of the 753 observations, there are only 22 with positive values for the number of cooperative innovations. For non-cooperative innovations, the corresponding figure is 34 . The zero-inflated negative binomial model provides a way of modeling such excess zeros, in addition to allowing for over-dispersion. ${ }^{8}$ For each observation, there

\footnotetext{
${ }^{8}$ The standard deviation of the number of innovations was six times the size of the mean. A simple tobit specification was not able to handle this over-dispersion. Although there were 30 cities that actually innovated, tobit estimates were
} 
are two possible data-generating processes. For observation $i$, the first process is chosen with probability $\varphi_{i}$ and the second with probability $1-\varphi_{i}$. The first process generates only zeros using a logit model. A possible determinant of this selection is the number of innovations in the preceding period, an indication of dynamic learning effects. The second process generates counts from a negative binomial model.

In general:

$$
\begin{aligned}
& I_{i j t}=0 \quad \text { with probability } \varphi_{\mathrm{i}} \\
& =\exp \left(\boldsymbol{X}_{i j t} \boldsymbol{\beta}+\varepsilon_{i j t}+u_{i j t}\right) \quad \text { with probability 1- } \varphi_{i},
\end{aligned}
$$

where $I_{i j t}$ is the expected number of innovations in city $i$ of type $j$ (cooperative or non-cooperative) in period t, $\boldsymbol{X}_{i j t}$ is a vector of explanatory variables, $\boldsymbol{\beta}$ is a vector of parameters, $\varepsilon_{i j t}$ is a random variable and $\exp \left(u_{i j t}\right)$ follows a gamma distribution.

\section{(b) The Urban-Growth Process}

We now turn to the process of urban population growth. Let us assume that the change in population in city $i$ during period $t$ is a function of its initial population, the number of innovations in that city during the period, and the number of innovations in other cities of the same country, the latter weighted by the distance from the city in question, an approximate measure of non-linguistic transaction costs.

$$
\Delta P_{i t}=\alpha_{1} P_{i 0}+\alpha_{2} I_{i t}+\gamma \sum_{j \neq i} d_{i j} I_{j t}+\boldsymbol{Z}_{i t} \boldsymbol{\delta}+v_{i t}
$$

where $P_{i 0}=$ population of city $i$ in period 0 ,

$$
\begin{aligned}
& I_{i t}=\text { number of innovations in city } i \text { in period } t, \\
& d_{i j}=\text { distance between cities } i \text { and } j, \\
& \boldsymbol{Z}_{i t}=\text { vector of other explanatory variables, } \\
& \boldsymbol{v}_{i t}=\text { error term. }
\end{aligned}
$$

positive only for Paris and London, whereas a zero-inflated negative binomial specification predicted that 20 cities would have more than 0.5 innovations in at least one half-century between 1700 and 1850 . 
Of particular interest are the parameters $\alpha_{2}$, a measure of the impact of innovation on economic growth and $\gamma$, which captures the externalities whereby all cities in a network benefit from the innovations in other cities in the same country.

In summary, this section has specified two equations to be estimated empirically. The first equation uses a zero-inflated negative binomial format to estimate the number of innovations in a given city during the three half centuries between 1700 and 1850. The second equation, to be estimated by ordinary least squares with an adjustment for robust clustered standard errors, assesses the effect of these innovations on the city's population growth. 


\section{Explaining Innovation}

The analysis of the preceding section suggested two steps to explain the appearance of rapid growth in clusters of innovating cities during the Industrial Revolution. The present section presents the estimates for the first step, explaining the development of new technologies in 251 urban areas of Western Europe and North America.

In Table 3, we see the results when the zero-inflated negative binomial specification of equation (1) in the preceding section is applied to our data set. Since city population is available only at 50-year intervals, observed innovations are grouped into the three half-centuries between 1700 and $1850 .{ }^{9}$ In column (1) are estimates for the 54 cooperative innovations (CIs); that is, those with two or more principals. In column (2) are separate estimates for the 63 non-cooperative innovations (NCIs); that is, those having a single inventor. Column (3) presents the results for all 117 innovations together. Note that among the confounding factors we have include a proxy for the initial degree of centralization; namely, whether the society had a city with a population of 200,000 or more in 1600 . As may be seen in Table 2, language standardization and this centralization variable are significantly correlated.

The upper section of Table 3 explains the number of new technologies developed in those cities that had a significant probability of innovating. We see that the impact of language standardization was important for CIs, indeed, significantly more important than institutional centralization. Since independent inventors too needed some minimal degree of support from suppliers and clients it is not surprising that the impact of language was statistically significant, though lower, for NCIs. As one would expect, larger cities tended to have a significantly greater number of innovations than smaller ones. Having nearby coal deposits (within $50 \mathrm{~km}$ or 31 miles) was also an important factor favouring innovation for both classes of innovations.

Consider now the lower part of the table which explains why a city or town failed to innovate. The dummy variables for Britain and France may perhaps be interpreted as a rough measure of cultural or institutional factors other than language or the degree of centralization; for example, differences

\footnotetext{
${ }^{9}$ Further disaggregation of the observations by date of innovation would unnecessarily complicate the test of causality.
} 
in religion as mentioned by Weber $(1905)^{10}$, patent laws and levels of taxation as emphasized by North (1981, 28, 164), or attitudes toward "useful knowledge" as suggested by Mokyr (2002, 2017). The significant positive signs for France suggest that once its national institutions had become centralized and its language standardized, other cultural and institutional factors had a negative effect on successful innovation.

In the case of Britain, the country dummy-variable coefficients for CIs and NCIs are both significant but with opposite signs. The positive sign in column (1) indicates that these other cultural and institutional factors had a negative effect on the number of joint innovations, though less so than in the case of France. At the same time, the significant negative Britain dummy variable for NCIs in column (2) indicates that the country's culture and institutions had a significant positive impact on the number of individual inventions. A possible explanation suggested by a comparison of the inventions in Appendix I is that many cooperative inventions, such as those of Boulton and Watt, involved high fixed costs that could be recuperated only if patent protection was obtainable to block competitors, whereas non-cooperative innovation had fixed costs sufficiently low that patent protection was not necessary to motivate those desiring to improve existing techniques. ${ }^{11}$ Finally, the negative coefficients for the two half-centuries beginning in 1750 and 1800 suggest that there was a significant improvement over time after 1750 in the capacity of many cities to innovate and therefore less need to inflate the probability of innovation. ${ }^{12}$

In summary, the results presented in Table 3 are compatible with the simple correlation coefficients of Table 2. Having taken account of institutional centralization, culture and factor supplies, we find a significant link running from language standardization prior to 1700 to subsequent innovation.

\footnotetext{
${ }^{10}$ Since between 1700 and 1850, Britain was predominantly Protestant and France was mostly Catholic, while Germany, Switzerland, the Low Countries, the United States,ion and Ireland had populations of mixed religions, the two country dummy variables and the constant capture religious differences quite well.

${ }^{11}$ In a recent survey, MacLeod and Nuvolari $(2016,82-83)$ pointed out that at least until the end of the eighteenth century, the British patent system tended to block innovation in capital-intensive sectors. In other word, culture and institutions had a negative effect on the number of innovations. However, in other sectors, much of British invention occurred without patent coverage (MacLeod, 1988, ch. 6); i.e., culture and institutions were favorable to innovation.

${ }^{12}$ Note that with the non-linear estimation method used, there is no equivalent of the F test for goodness of fit; however, the p-values together indicate that the probability that all coefficients are zero is negligible in each column of Table 3 .
} 


\section{Explaining Urban Population Growth}

In this part, we turn to the second relationship presented in Section 3; namely, the link between the number of innovations in a city and its population growth. We begin by evaluating the relative importance of possible factors explaining urban growth. We then correct for possible feedback from growth to innovation using the prior presence of a descriptive monolingual dictionary as an instrumental variable. Finally, we examine the sensitivity of our results to minor changes in specification.

\section{(a) The Explanatory Equation}

Consider first a specification for equation (2) above. The dependent variable is the population increase in thousands in a given city within a given 50-year period. Column (1) of Table 4 presents least-squares robust cluster estimates that distinguish the growth impact of the 54 cooperative innovations (CIs) from those of the 63 non-cooperative innovations (NCIs), but neglect the possibility of feedback from growth to innovation. We see that CIs in a city had a statistically significant relationship to population growth while NCIs did not. Moreover, CIs in the country as a whole, lagged one period, were also statistically significant. The latter result may be interpreted as an indication of important network externalities from previous major innovations within the same language area. As for the lagged impact of NCIs, there was no significant effect.

Most of the other explanatory variables in column (1) were not significant; for example, the literacy rate, whether the city was a capital or an Atlantic port, or whether the city was a printing center in 1500. Nor were distance from the capital, the period dummies, or the France country dummy variable significant. However, a dummy variable for Paris during the half-century from 1750 to 1799 was negative and highly significant. The city had grown rapidly until 1789, but emigration of the nobility and the economic hardships due to the Revolution led to an absolute fall in the city's population over the following decade (Fierro, 1996, 218-283). It is interesting to note that coal deposits did not have a direct impact on urban growth. Their influence, as shown in Table 3, seems

to have been indirect - through the incentive to innovate. As for the results in column (2) lumping all 117 innovations together, they are consistent with the preceding analysis. 


\section{(b) Instrumental-variable Estimates}

However, correlation need not imply causality. Accordingly, in columns (3) and (4) of Table 4 we use an instrumental-variable (IV) procedure to test for possible feedback from population growth to innovation. If, as explained in Section 1, having a standard language facilitated the communication and trust necessary for successful innovation, then the presence of a monolingual usage dictionary in 1700 may serve as an instrument for the number of subsequent innovations in a city. There are two necessary conditions for using instrumental variables. First, the instrument must be significantly strong as measured by its correlation with the endogenous variable it replaces. The correlation coefficients of the instrument, "Standard language", with "All innovations", "Cooperative innovations" and "Non-cooperative innovations" are 0.19, 0.16 and 0.17 respectively, all significant at the 0.01 level. Second, the instrument must satisfy the exclusion restriction; that is, it must not be correlated with the error term in the explanatory equation. The correlation coefficients of "Standard language" with the residuals of equations (1) and (2) of Table 4, are 0.008 and 0.018 respectively, neither of which is significant at the 0.01 level. Accordingly, language standardization as measured by the existence of a monolingual dictionary, satisfies the preconditions for IV estimation.

Compare, then, the IV estimates in column (3) of Table 4 with those of the explanatory equation in column (1). In the former, the observed values of cooperative and non-cooperative innovations have been replaced by estimates calculated from columns (1) and (2) of Table 3, in effect using the presence of a monolingual dictionary in 1700 as instrument. Not only are the IV estimates for the impact of cooperative and non-cooperative innovations (CIs and NCIs respectively) in a given city positive, but also, they are significantly greater than those of the evaluation-equation estimates in column (1). Other things being equal, a CI in a city was accompanied by a population increase of almost 44,000 during the same half century, while a non-cooperative innovation caused population to grow by some 32,000. A comparison of columns (4) and (2) of Table 4 leads to a similar conclusion for all innovations. We see that there was apparently negative feedback from growth to innovation. An increase in the number of residents in a city would appear to have reduced the number of innovations, other things being equal!

Why might feedback from population growth have reduced the number of innovations in a city? A comparison of simple averages of innovations by city size for the 30 centers that generated positive innovations between 1700 and 1750 suggests a possible explanation. The first two lines of Table 5 
show that over the century and a half in question, the 25 smaller innovating cities with populations under 50,000 generated on average 36 innovations per 100,000 inhabitants. Well over half of these innovations were cooperative. Meanwhile, the five larger innovating cities generated on average only 3 innovations per 100,000 of population, over two-thirds of which were non-cooperative.

Not only did having a large population considerably reduce a city's rate of innovation, but also large size discouraged cooperative innovation considerably more than non-cooperative innovation. A possible explanation is that under the transportation and communications technologies of the period, larger cities implied higher transactions costs than their smaller neighbors. These higher costs of interacting within the largest centers appear to have been especially costly for groups of individuals who needed to combine their individual skills in order to generate novelty. Note, however, that almost all these cooperative innovations were in the standardized-language clusters of Figure 1.

\section{(c) Robustness}

How sensitive are the results of the disaggregated specifications in columns (1) and (3) of Table 4 to the inclusion of certain explanatory variables rather than others? In the robustness tests reported in Table 6, the six core variables appear in all of the specifications. Each of the remaining tested explanatory variables appears in one specification for every possible combination of all but one of the other tested variables. The results for the IV estimates indicate that the coefficients of cooperative and non-cooperative innovations in a given city remain consistently positive and significant. In both cases, the differences in the means of the coefficients suggest negative feedback from population change to innovation. As for lagged innovations, the IV estimates indicate that the impact of cooperative innovations from the preceding half-century was consistently positive and significant. The remaining results show that the positive effect of initial population and the negative effect of the French Revolution are also quite robust. However, the effects of all of the other explanatory variables are fragile, depending on the specification.

In summary, the initial explanatory-equation estimates support the hypothesis of a significant positive relationship between innovation in a given city, particularly cooperative innovation, and its population growth. An examination of the question of causation reinforces these findings. There is no evidence of positive contemporaneous feedback by which a city's population growth might have stimulated its rate of innovation. Moreover, cooperative innovations within the boundaries of the present-day country also promoted a city's growth in later periods. It may be suggested that the 
concentration of innovation and rapid population growth in clusters of cities in Britain, France and the United States between 1700 and 1850 may be explained, at least in part, by the network effects of language standardization. 


\section{Conclusion}

The results of this research are compatible with those of earlier studies, providing support for the importance of culture, social institutions, and geography in determining economic growth in the West between 1700 and 1850. However, our estimates also suggest that explicit consideration of the standardization of the English and French languages helps explain three often-overlooked facts about innovation and urbanization during this period.

First, the standardization by 1700 of the dialects spoken by educated residents of Western Europe's largest cities was significantly related to subsequent innovation in three urban clusters in Britain, northern France and the USA. Once standardized in written form through the printing press, these dialects subsequently spread to smaller urban centers. We found the positive effect of language standardization on innovation to be distinct from the influence of institutional centralization, changes in relative factor prices and other aspects of national cultures.

Second, the relatively large number of innovations in these three regions between 1700 and 1850 in turn played a significant role in determining their rapid urbanization. In other regions of the West with little innovation, cities generally grew less rapidly than rural areas. Moreover, using publication dates of the first monolingual dictionaries as an instrument for innovation, we found no evidence of positive contemporaneous feedback from urban population growth to innovation.

Third, a major factor explaining a causal link from innovation to urban growth would appear to have been the ability of a standard language to facilitate communication between potential innovators who had different areas of specialization and came from different cities. The contributions of the resulting "cooperative innovations" - such as the steam engine, industrial chemicals, or production with standardized parts - to urban growth were significantly greater than those of "non-cooperative" innovations; that is, those involving a single inventor. Nevertheless, independent inventors too seem to have benefited from language standardization - possibly because even market-determined contracts require good faith on the part of all parties.

Our results suggest that Metcalfe's (2013) Law applies not only to internet networks but also to language standardization. Squaring the number of users is as helpful in understanding urban growth during the Industrial Revolution as in explaining the rise in the revenues of Facebook. 


\section{Data sources}

Atlantic port. Hammond Ambassador World Atlas. Union, N.J.: Hammond World Atlas Corp., 1992.

City population. The sample consisted of cities with populations over 5,000 in 1700 in the innovation space defined in Section 2(a) of text. Population estimates for European cities were from Bairoch et al. (1988) as revised by Voigtländer and Voth (2013). Estimates for New York, Philadelphia and Boston were from Longman Publishing (2019).

Coal. The identification of cities with coal deposits within 30 miles (48 km) was obtained from Barraclough (1984: 201, 210-211).

Country population. Maddison $(2007,376)$.

Distances. The driving distance in kilometres to each city from the respective national capital were obtained from Google Maps, https://maps.google.com/.

GDP. Maddison (2007, 379).

Innovations. See Section 2(a) of text.

Language standardization. Cities in Belgium and Switzerland were assigned the dates of French, Dutch or German dictionaries, depending on their main languages. As for Scotland, by the year 1700, educated Scots were growing accustomed to using English rather than the Scottish dialect for formal communication (Herman, 2001, p. 116). A similar argument applies to Ireland only a century later. In the case of the United States, at least as early as 1666, Phillips's New World was being sold in Boston (Considine, 2015, 218).

Literacy. For signature rates at marriage by country, the sources were England: Cressy (1980, 177); Scotland: Stone (1969, 121); France: Houdaille (1977, 68); Germany: Hofmeister et al. (1998); Italy: Reis (2005, 202); Netherlands: van der Woude (1980, 257-264); Spain: Roser (2016); United States: Graff $(1991,249)$.

Printing centers in 1700: Febvre and Martin (1976) and Sasaki (2017). 


\section{References}

Acemoglu, Daron, and James A. Robinson, Why Nations Fail: The Origins of Power, Prosperity and Poverty. London: Profile Books, 2012.

Allen, Robert C., The British Industrial Revolution in Global Perspective. Cambridge: Cambridge University Press, 2009.

Alvar Ezquerra, Manuel, "El Tesoro de Sebastián de Covarrubias, primer diccionario monolingüe del Español," Académica, 6 (2011), 31-82.

Bairoch, Paul, J. Batou, and P. Chèvre, The Population of European Cities, 800-1850. Geneva: Librairie Droz, 1988.

Barraclough, Geoffrey, editor, The Times Atlas of World History. Maplewood, N.J.: Hammond, 1984.

Baugh, Albert C. and Thomas Cable, A History of the English Language, fourth edition. London: Routledge, 1993.

Bell, David A., "Culture and Religion," Chapter 3 in Old Regime France: 1648-1788, William Doyle (ed.), 78-104. Oxford: Oxford University Press, 2001.

Cardwell, D. S. L., Turning Points in Western Technology. Canton, MA: Science History Publications/USA, 1991.

Carriazo Ruiz, J. R. and J. Mancho Duque, "Los comienzos de la lexicografía monolingüe," en Antonia M. Medina Guerra (ed.), Lexicografía española. Barcelona: Ariel, 2003, pp. 222-223.

Ciccarelli, Carlo and Jacob Weisdorf, "Pioneering into the Past: Regional Literacy Developments in Italy before Italy," European Review of Economic History, 23 (2019), 329-364.

Clark, Gregory, A Farewell to Alms: A Brief Economic History of the World. Princeton: Princeton University Press, 2009.

Considine, John, "In Praise of Edward Phillips," Studia Linguistica Universitatis Iagellonicae Cracoviensis, 132 (2015): 211-228.

Cressy, David, Literacy and the Social Order: Reading and Writing in Tudor and Stuart England. Cambridge: Cambridge University Press, 1980.

Crystal, David, The Cambridge Encyclopedia of the English Language, Second Edition, Cambridge, Cambridge University Press, 2003.

Daumas, Maurice, A History of Technology and Invention, Volume III, The Expansion of Mechanization, 1725-1860. New York: Crown Publishers, 1979.

Daumas, Maurice, A History of Technology and Invention, Volume II, The First Stages of Mechanization, 1450-1725. London: John Murray, 1980.

Desmet, Klaus, Avner Greif and Stephen L. Parente, "Spatial Competition, Innovation and Institutions: The Industrial Revolution and the Great Divergence." Journal of Economic Growth, 2019, pp 1-35, https://doi.org/10.1007/s10887-019-09173-3

Dittmar, Jeremiah E., "Information Technology and Economic Change: The Impact of the Printing Press," Quarterly Journal of Economics (2011) 126, 1133-1172.

Dudley, Leonard, "Language Standardization and the Industrial Revolution", Oxford Economic Papers, 69:4 (2017), 1138-1161.

Febvre, Lucien and Henri-Jean Martin, The Coming of the Book. London: Verso, 1976.

Fierro, Alfred, Histoire et dictionnaire de Paris. Paris: Bouquins, 1996. 
Fiske, S. T., Cuddy, A. J. and Glick, P., "Universal Dimensions of Social Cognition: Warmth and Competence", Trends in Cognitive Sciences, 11 (2007), 77-83.

Graff, Harvey J., The Legacies of Literacy. Bloomington, Indiana, USA: Indiana University Press, 1991.

Herman, Arthur, How the Scots Invented the Modern World. New York: Three Rivers Press, 2001. Hofmeister, Andrea, Reiner Prass and Norbert Winnige, "Elementary Education, Schools and the Demands of Everyday Life: North West Germany in 1800," Central European History, 31 (1998), 329-384.

Houdaille, Jacques, "Les signatures au mariage de 1740 à 1829," Population, 32 (1977), 65-90. Jackson, Howard, Lexicography: An Introduction. New York: Routledge, 2002.

Joseph, John Earl, Eloquence and Power: The Rise of Language Standards and Standard Languages. Oxford: Basil Blackwell, 1988.

Kloss, Heinz, "'Abstand Languages' and 'Ausbau Languages'", Anthropological Linguistics, 9 (1967), 29-41.

Landes, David S., The Wealth and Poverty of Nations: Why Some Are So Rich and Some Are So Poor. New York, Norton, 1998.

Lev-Ari, S. and Keysar, B., "Why Don't We Believe Non-Native Speakers? The Influence of Accent on Credibility", Journal of Experimental Social Psychology, 11 (2010), 77-83.

Longman Publishing, “Ten Largest Cities by Population, 1700-2000,” 2019, http://wps.ablongman.com/wps/media/objects/244/250688/Appendix/12.pdf.

MacLeod, Christine, Inventing the Industrial Revolution: The English Patent System, 1660-1800. Cambridge: Cambridge University Press, 1988.

MacLeod, Christine, and Alessandro Nuvolari, "Inventive Activities, Patents and Early Industrialisation: A Synthesis of Research Issues," Rivista di storia economica, 32:1, April 2016, 77-108.

Maddison, Angus, Contours of the World Economy, 1-2030 AD: Essays in Macro-Economic History. Oxford: Oxford University Press, 2007.

McCloskey, Dierdre, Bourgeois Dignity: Why Economics Can't Explain the Modern World. Chicago: University of Chicago Press, 2010.

Metcalfe, Bob, "Metcalfe's Law after 40 Years of Ethernet," Computer, 46 (2013), 26 - 31. Mokyr, Joel, The Lever of Riches: Technological Creativity and Economic Progress. Oxford: Oxford University Press, 1990.

Mokyr, Joel, The Gifts of Athena : Historical Origins of the Knowledge Economy. Princeton, NJ: Princeton University Press, 2002.

Mokyr, Joel, A Culture of Growth: The Origins of the Modern Economy. Princeton: Princeton University Press, 2017.

Moser, Petra, How Do Patent Laws Influence Innovation? Evidence from Nineteenth-Century World's Fairs, American Economic Review, 95 (2005), 1214-1236.

Nicholson, Adam, God's Secretaries: The Making of the King James Bible. New York: HarperCollins, 2003.

North, Douglass C., Structure and Change in Economic History. New York: Norton, 1981.

North, Douglass C., Institutions, Institutional Change, and Economic Performance. Cambridge: Cambridge University Press, 1990. 
Paulinyi, Akos, Industrielle Revolution: Vom Ursprung der modernen Technik. Reinbek bei Hamburg, Germany: Rowohlt, 1989.

Polimeni, Giuseppe, "Usage in the Lexicography of Italian: Two Viewpoints and a Few Basic Reflections," Dictionaries: Journal of the Dictionary Society of North America, 40 (2019), 117-132.

Pomeranz, Kenneth, (2000). The Great Divergence: China, Europe, and the Making of the Modern World Economy. Princeton, NJ: Princeton University Press.

Rees, Fran, Johannes Gutenberg: Inventor of the Printing Press, Minneapolis: Compass Point Books, 2006.

Reis, Jaime, "Economic Growth, Human Capital Formation, and Consumption in Western Europe before 1800," in Living Standards in the Past: New Perspectives on Well-being in Asia and Europe, by Robert C. Allen, Tommy Bengtsson and Martin Dribe. Oxford: Oxford University Press, 2005, 195-225.

Roser, Max and Esteban Ortiz-Ospina, "Literacy," (2016). Published online at OurWorldInData.org. Retrieved from: 'https://ourworldindata.org/literacy'.

Sasaki, Yu, "Publishing Nations: Technology Acquisition and Language Standardization for European Ethnic Groups,” Journal of Economic History, 77 (2017), 1007-1047.

Squicciarini, Mara P., and Nico Voigtländer, "Human Capital and Industrialization: Evidence from the Age of Enlightenment," Quarterly Journal of Economics, 130 (2015), 1825-1883.

Stone, Lawrence, "Literacy and Education in England 1640-1900," Past \& Present, 42 (1969), 69139.

Sumner, M. and Samuel, A. G. "The Role of Experience in the Processing of Cross-Dialectal Variation", Journal of Memory and Language, 60 (2009), 487-501.

Sumner, M., "The Social Weight of Spoken Words, Trends in Cognitive Sciences", 19 (2015), 238239.

Tann, Jennifer, "Watt, James," Oxford Dictionary of National Biography, 2014. Online version: https://doi.org/10.1093/ref:odnb/28880

Uglow, Jenny, The Lunar Men: Five Friends Whose Curiosity Changed the World. New York: Farrar, Strauss and Giroux, 2002.

van der Woude, A. M., "De alfabetisering," Algemene Geschiednis der Nederlanden, 7 (1980): 257264.

Vincent, Nigel, "Italian," in Bernard Comrie, ed., The World's Major Languages. Oxford: Oxford University Press, 1990, 279-302.

Voigtländer, Nico, and Hans-Joachim Voth, "The Three Horsemen of Riches: Plague, War, and Urbanization in Early Modern Europe," Review of Economic Studies, 80, (2013), 774-811.

Vuola, Olli and Ari-Pekka Hameric, "Mutually Benefiting Joint Innovation Process between Industry and Big-Science," Technovation, 26 (2006), 3-12.

Weber, Max, The Protestant Ethic and the Spirit of Capitalism. London: Routledge, [1905] 1992.

Wojciszke, B., Bazinska, R. and Jaworski, M. "On the Dominance of Moral Categories in Impression Formation”, Personality and Social Psychology Bulletin, 24 (1998), 1245-1257. 


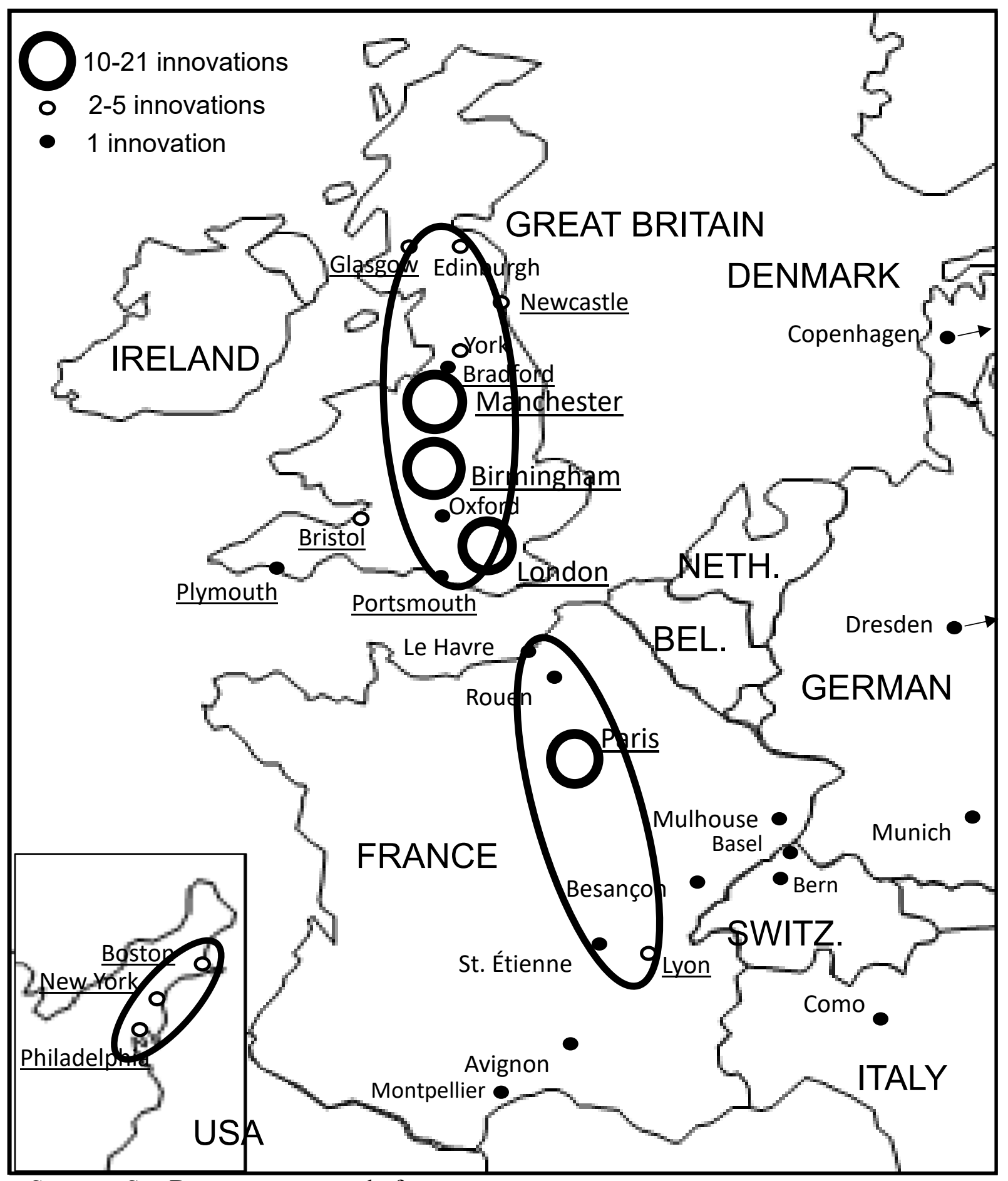

Sources: See Data sources at end of text.

Figure 1. Innovating cities during the Industrial Revolution, 1700-1850 (underlined cities had at least one cooperative innovation) 


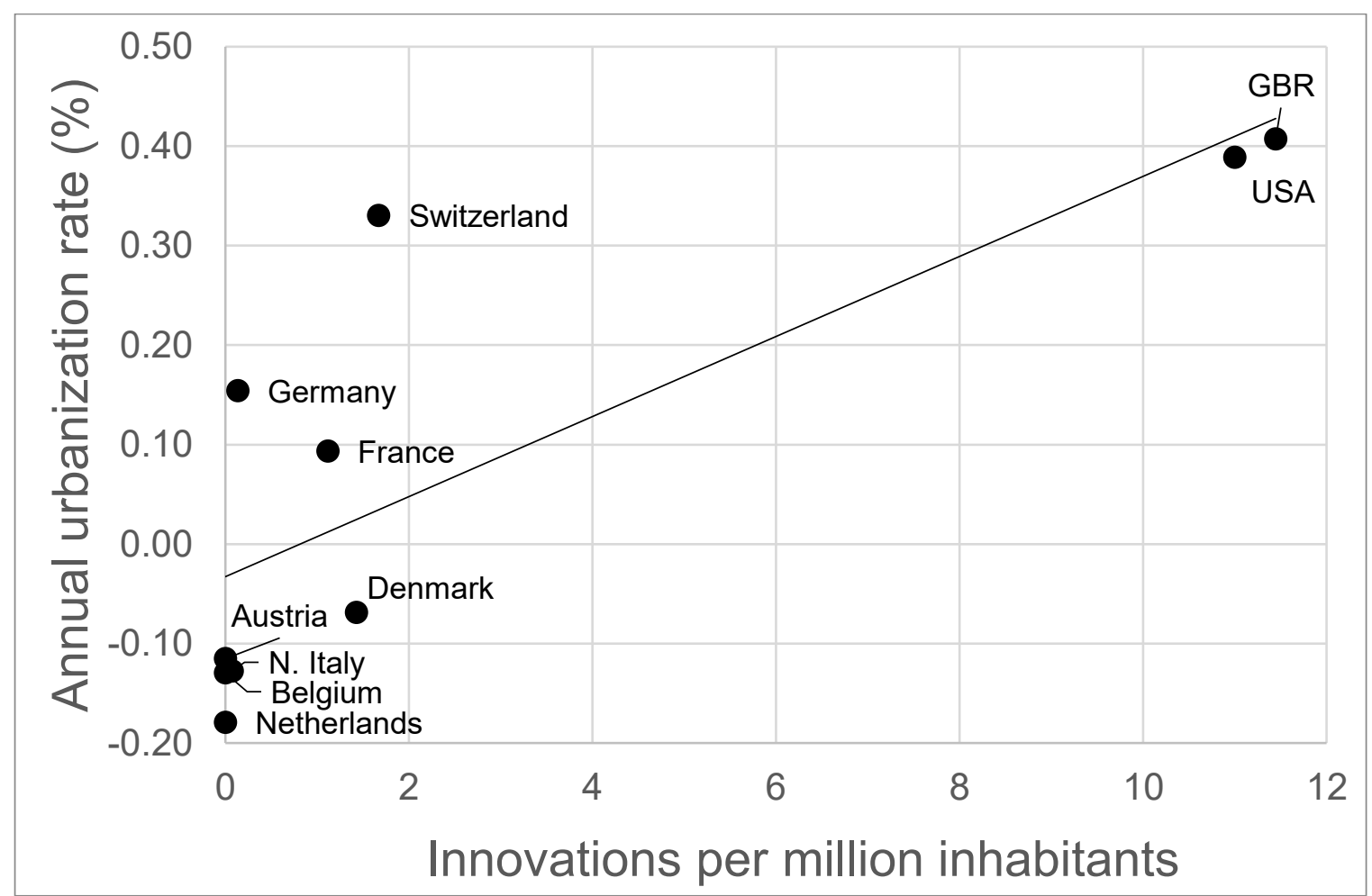

Sources: See Data sources at end of text.

Figure 2. Annual innovation and urbanization growth rates, 1700-1850 
Table 2. Correlation coefficients between dependent and explanatory variables

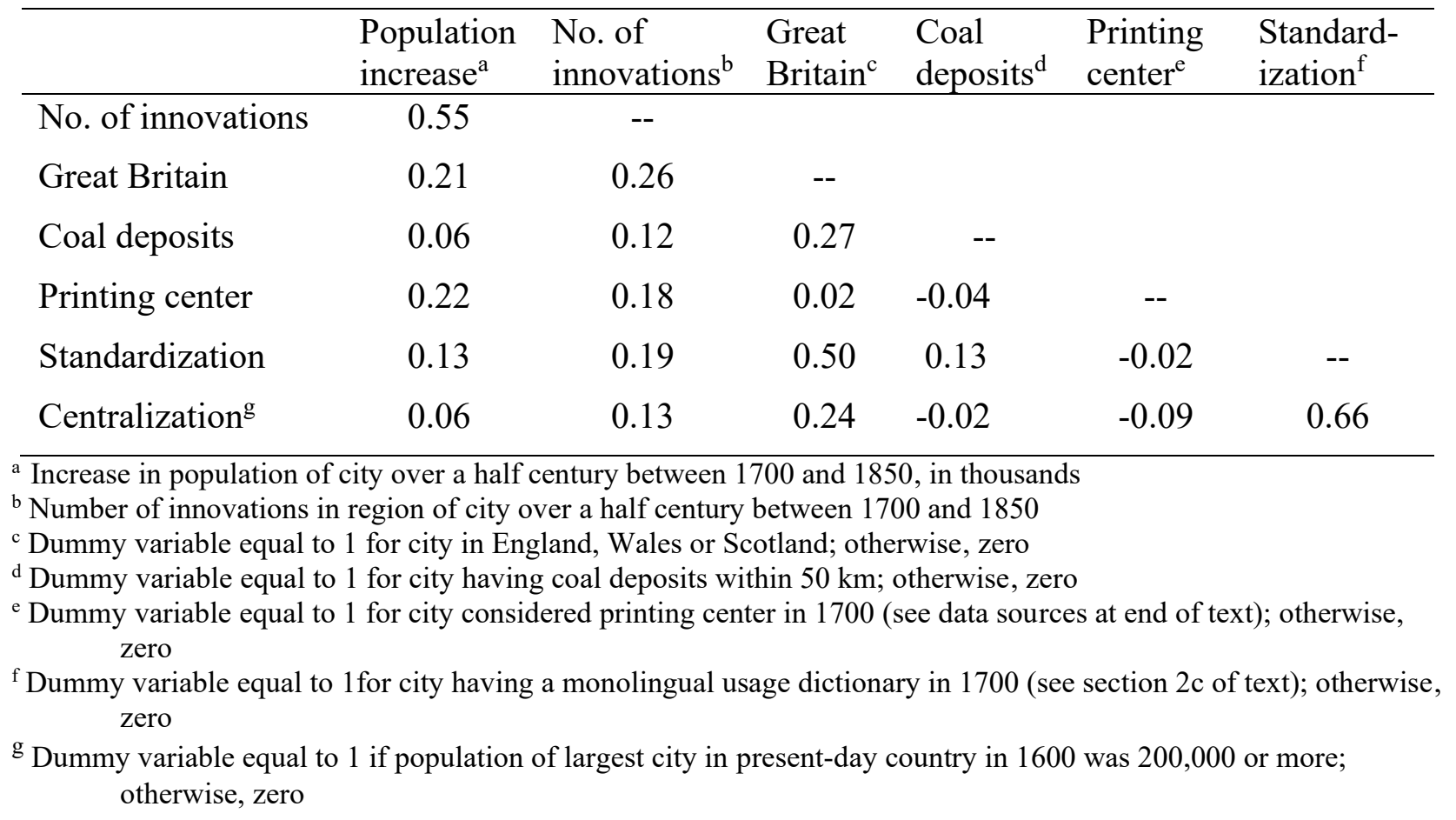


Table 3. Factors influencing innovation rates, 1700-1849

\begin{tabular}{|c|c|c|c|}
\hline & $\begin{array}{c}\text { Cooperative } \\
\text { (1) }\end{array}$ & $\begin{array}{c}\text { Non-cooperative } \\
\text { (2) }\end{array}$ & $\begin{array}{c}\text { All innovations } \\
\text { (3) }\end{array}$ \\
\hline \multicolumn{4}{|c|}{ Number of innovations: } \\
\hline Standardization & $\begin{array}{l}18.14^{* * *} \\
(0.6452)\end{array}$ & $\begin{array}{c}1.278^{* *} \\
(0.4393)\end{array}$ & $\begin{array}{l}1.958^{* * *} \\
(0.5780)\end{array}$ \\
\hline Centralization & $\begin{array}{l}1.702^{* * *} \\
(0.0387)\end{array}$ & $\begin{array}{c}0.874^{*} \\
(0.3840)\end{array}$ & $\begin{array}{l}1.284^{* * *} \\
(0.3607)\end{array}$ \\
\hline Initial population & $\begin{array}{c}0.00285^{* * *} \\
(0.0004)\end{array}$ & $\begin{array}{c}0.00585^{* * *} \\
(0.0011)\end{array}$ & $\begin{array}{c}0.00456^{* * *} \\
(0.0013)\end{array}$ \\
\hline Coal deposits & $\begin{array}{l}1.649^{* * *} \\
(0.2294)\end{array}$ & $\begin{array}{c}1.271^{*} \\
(0.5146)\end{array}$ & $\begin{array}{l}1.341^{* * *} \\
(0.3287)\end{array}$ \\
\hline Constant & $\begin{array}{l}-20.59^{* * *} \\
(0.6753)\end{array}$ & $\begin{array}{l}-4.198^{* * *} \\
(0.8594)\end{array}$ & $\begin{array}{l}-4.174^{* * *} \\
(0.7998)\end{array}$ \\
\hline \multicolumn{4}{|l|}{ Inflation of zeros: } \\
\hline Great Britain & $\begin{array}{l}1.757^{* * *} \\
(0.2217)\end{array}$ & $\begin{array}{l}-33.68^{* * *} \\
(1.2889)\end{array}$ & $\begin{array}{c}0.435 \\
(1.4694)\end{array}$ \\
\hline France & $\begin{array}{l}4.619^{* * *} \\
(0.1202)\end{array}$ & $\begin{array}{c}2.550^{*} \\
(1.1274)\end{array}$ & $\begin{array}{l}3.461^{* * *} \\
(0.9102)\end{array}$ \\
\hline $1750-1799$ & $\begin{array}{c}-1.298^{* * *} \\
(0.2556)\end{array}$ & $\begin{array}{l}-1.598^{*} \\
(0.7267)\end{array}$ & $\begin{array}{l}-1.347^{* *} \\
(0.4639)\end{array}$ \\
\hline $1800-1849$ & $\begin{array}{l}-2.928^{* * *} \\
(0.0629)\end{array}$ & $\begin{array}{l}-3.436^{* * *} \\
(0.7687)\end{array}$ & $\begin{array}{c}-3.227^{* * *} \\
(0.5621)\end{array}$ \\
\hline Constant & $\begin{array}{c}0.368^{* *} \\
(0.1384)\end{array}$ & $\begin{array}{l}-0.0364 \\
(1.5937)\end{array}$ & $\begin{array}{c}-0.199 \\
(1.2242)\end{array}$ \\
\hline lnalpha & $\begin{array}{l}-0.798^{* *} \\
(0.3042)\end{array}$ & $\begin{array}{l}0.817^{* * *} \\
(0.0606)\end{array}$ & $\begin{array}{c}0.386^{*} \\
(0.1918) \\
\end{array}$ \\
\hline $\begin{array}{l}\text { N } \\
\text { Log likelihood }\end{array}$ & $\begin{array}{c}753 \\
-83.38 \\
\end{array}$ & $\begin{array}{c}753 \\
-142.2 \\
\end{array}$ & $\begin{array}{c}753 \\
-183.0 \\
\end{array}$ \\
\hline \multicolumn{4}{|c|}{$\begin{array}{l}\text { Zero inflated negative binomial regressions with robust clustered standard errors } \\
\text { Dependent variable: number of innovations in city during } 50 \text {-year period. }\end{array}$} \\
\hline
\end{tabular}


Table 4. Factors influencing urban population growth, in thousands, 1700-1849

\begin{tabular}{|c|c|c|c|c|}
\hline & \multicolumn{2}{|c|}{ Explanatory equation } & \multicolumn{2}{|c|}{ Instrumental-variable estimates } \\
\hline & (1) & (2) & (3) & (4) \\
\hline \multicolumn{5}{|l|}{ Current innovations: } \\
\hline All innovations in given city & & $\begin{array}{c}16.36^{* *} \\
(3.0053)\end{array}$ & & $\begin{array}{c}34.32^{* * *} \\
(2.9952)\end{array}$ \\
\hline Coop. innovations in given city & $\begin{array}{c}25.14^{*} \\
(8.1114)\end{array}$ & & $\begin{array}{c}43.70^{* *} \\
(5.4688)\end{array}$ & \\
\hline Non-coop. innovations in given city & $\begin{array}{c}5.301 \\
(3.5415)\end{array}$ & & $\begin{array}{l}31.95^{* * *} \\
(2.9903)\end{array}$ & \\
\hline \multicolumn{5}{|l|}{ Lagged innovations: } \\
\hline All innovations in same country & & $\begin{array}{c}1.719^{*} \\
(0.4929)\end{array}$ & & $\begin{array}{c}1.298^{*} \\
(0.4113)\end{array}$ \\
\hline Coop. innovations in same country & $\begin{array}{l}3.764^{* * *} \\
(0.1223)\end{array}$ & & $\begin{array}{l}3.002^{* * *} \\
(0.1471)\end{array}$ & \\
\hline Non-coop. innov. in same country & $\begin{array}{c}-0.222 \\
(0.1730)\end{array}$ & & $\begin{array}{l}-0.482^{*} \\
(0.1496)\end{array}$ & \\
\hline Initial population & $\begin{array}{c}0.647^{*} \\
(0.1431)\end{array}$ & $\begin{array}{c}0.660^{* *} \\
(0.1319)\end{array}$ & $\begin{array}{c}0.284^{*} \\
(0.1024)\end{array}$ & $\begin{array}{c}0.283 \\
(0.1080)\end{array}$ \\
\hline Coal deposits & $\begin{array}{c}2.925 \\
(2.6002)\end{array}$ & $\begin{array}{c}2.558 \\
(2.3996)\end{array}$ & $\begin{array}{c}-0.697 \\
(2.4356)\end{array}$ & $\begin{array}{c}0.849 \\
(2.8522)\end{array}$ \\
\hline Capital city & $\begin{array}{c}-5.090 \\
(15.0937)\end{array}$ & $\begin{array}{c}-7.909 \\
(14.4535)\end{array}$ & $\begin{array}{c}13.42^{*} \\
(2.9618)\end{array}$ & $\begin{array}{c}13.01^{*} \\
(3.3420)\end{array}$ \\
\hline Atlantic port & $\begin{array}{c}-3.153 \\
(3.8839)\end{array}$ & $\begin{array}{c}-3.022 \\
(3.9934)\end{array}$ & $\begin{array}{c}2.169 \\
(6.0402)\end{array}$ & $\begin{array}{c}2.515 \\
(6.1868)\end{array}$ \\
\hline Distance from capital & $\begin{array}{c}0.0149^{*} \\
(0.0050)\end{array}$ & $\begin{array}{c}0.0112 \\
(0.0056)\end{array}$ & $\begin{array}{c}0.0130^{*} \\
(0.0034)\end{array}$ & $\begin{array}{c}0.0102^{*} \\
(0.0032)\end{array}$ \\
\hline Literacy rate & $\begin{array}{c}0.143 \\
(0.1040)\end{array}$ & $\begin{array}{c}0.159 \\
(0.0921)\end{array}$ & $\begin{array}{c}0.136 \\
(0.1022)\end{array}$ & $\begin{array}{c}0.142 \\
(0.0935)\end{array}$ \\
\hline Printing center & $\begin{array}{c}-20.17 \\
(10.0058)\end{array}$ & $\begin{array}{c}-21.32 \\
(10.1161)\end{array}$ & $\begin{array}{l}-10.70^{*} \\
(3.3246)\end{array}$ & $\begin{array}{l}-11.15^{*} \\
(3.4222)\end{array}$ \\
\hline French Revolution & $\begin{array}{l}-455.9^{* * *} \\
(50.7246)\end{array}$ & $\begin{array}{l}-511.1^{* * *} \\
(16.6646)\end{array}$ & $\begin{array}{c}-195.9^{*} \\
(58.3318)\end{array}$ & $\begin{array}{c}-193.5^{*} \\
(62.9946)\end{array}$ \\
\hline Great Britain & $\begin{array}{l}-18.23^{* *} \\
(3.8016)\end{array}$ & $\begin{array}{c}-16.45 \\
(10.2374)\end{array}$ & $\begin{array}{l}-24.68^{* *} \\
(3.0208)\end{array}$ & $\begin{array}{c}-21.51 \\
(9.5426)\end{array}$ \\
\hline France & $\begin{array}{l}-3.685 \\
(2.4457)\end{array}$ & $\begin{array}{c}-9.760 \\
(4.2991)\end{array}$ & $\begin{array}{c}-2.385 \\
(1.2817)\end{array}$ & $\begin{array}{l}-7.800^{*} \\
(2.5382)\end{array}$ \\
\hline $1750-1799$ & $\begin{array}{c}-3.002 \\
(4.6969)\end{array}$ & $\begin{array}{c}-5.898 \\
(5.5383)\end{array}$ & $\begin{array}{c}-2.275 \\
(3.4341)\end{array}$ & $\begin{array}{c}-4.739 \\
(4.3214)\end{array}$ \\
\hline $1800-1849$ & $\begin{array}{c}2.849 \\
(5.4411)\end{array}$ & $\begin{array}{c}-3.840 \\
(8.0398)\end{array}$ & $\begin{array}{c}5.348 \\
(4.0888)\end{array}$ & $\begin{array}{c}-0.235 \\
(7.3277)\end{array}$ \\
\hline Constant & $\begin{array}{l}-14.84^{* *} \\
(2.7601)\end{array}$ & $\begin{array}{l}-12.48^{* *} \\
(2.0661)\end{array}$ & $\begin{array}{l}-9.833^{* *} \\
(1.9863)\end{array}$ & $\begin{array}{c}-7.569^{*} \\
(2.3219)\end{array}$ \\
\hline $\begin{array}{l}\text { Number of observations } \\
\text { adj. } R^{2}\end{array}$ & $\begin{array}{c}753 \\
0.696 \\
\end{array}$ & $\begin{array}{c}753 \\
0.681\end{array}$ & $\begin{array}{c}753 \\
0.825 \\
\end{array}$ & $\begin{array}{c}753 \\
0.817\end{array}$ \\
\hline
\end{tabular}

Ordinary least squares regressions with robust clustered standard errors

Dependent variable: change in population of city during 50 -year period, in thousands.

Standard errors in parentheses

Number of observations: 753

${ }^{*} p<0.05,{ }^{* *} p<0.01,{ }^{* * *} p<0.001$ 
Table 5. Innovations per hundred thousand inhabitants in innovating cities, 1700-1850

\begin{tabular}{|c|c|c|c|}
\hline \multirow{3}{*}{$\begin{array}{l}\text { Innovations per } 100,000 \\
\text { inhabitants: }\end{array}$} & \multicolumn{3}{|c|}{ Population of city in 1700} \\
\hline & Under 50,000 & Over 50,000 & All cities \\
\hline & & & \\
\hline Cooperative & 19.2 & 0.08 & 16.1 \\
\hline Non-cooperative & 16.8 & $\underline{0.21}$ & 14.4 \\
\hline All innovations & 36.0 & 0.29 & 30.5 \\
\hline Number of innovations & 77 & 40 & 117 \\
\hline Number of innovating cities & 25 & 5 & 30 \\
\hline Total number of cities & 229 & 22 & 251 \\
\hline Total population (thousands): & & & \\
\hline Innovating cit & 356 & 1,287 & 1,643 \\
\hline All cities & 3,116 & 2,232 & 5,348 \\
\hline
\end{tabular}


Table 6. Robustness: Impact of disaggregated innovations on urban population growth ('000)

\begin{tabular}{|c|c|c|c|c|c|c|c|}
\hline \multirow[b]{2}{*}{ Core variables } & \multicolumn{3}{|c|}{ Explanatory equation* } & \multicolumn{3}{|c|}{ IV estimation** } & \multirow[b]{2}{*}{ Obs. } \\
\hline & Mean & FracSigni & Fract & Mean & FracSigni & Frac + & \\
\hline Initial population & 0.67 & 1 & 1 & 0.47 & 1 & 1 & 1024 \\
\hline Great Britain & -5.32 & 0.72 & 0.31 & -13.69 & 0.83 & 0.19 & 1024 \\
\hline France & -4.91 & 0.22 & 0.07 & -4.64 & 0.28 & 0.05 & 1024 \\
\hline French Revolution & -455.51 & 1 & 0 & -282.34 & 1 & 0 & 1024 \\
\hline $1750-1749$ & -1.92 & 0.05 & 0.17 & -1.86 & 0.03 & 0.11 & 1024 \\
\hline $1800-1849$ & 5.41 & 0.22 & 0.91 & 5.64 & 0.19 & 0.97 & 1024 \\
\hline Tested variables & Mean & FracSigni & Frac + & Mean & FracSigni & Frac+ & Obs. \\
\hline \multicolumn{8}{|l|}{ Current innovations: } \\
\hline Cooperative in given city & 19.92 & 1 & 1 & 79.53 & 1 & 1 & 512 \\
\hline Non-coop. in given city & 8.38 & 0.33 & 0.88 & 34.76 & 1 & 1 & 512 \\
\hline \multicolumn{8}{|l|}{ Lagged innovations: } \\
\hline Coop. in same country & 3.95 & 1 & 1 & 3.10 & 1 & 1 & 512 \\
\hline Non-coop. in same c'try & 1.04 & 0 & 0.56 & 0.62 & 0.25 & 0.56 & 512 \\
\hline Coal deposits & 4.96 & 0 & 1 & 0.42 & 0 & 0.52 & 512 \\
\hline Capital city & -10.97 & 0 & 0 & 2.01 & 0.41 & 0.65 & 512 \\
\hline Atlantic port & -2.72 & 0 & 0 & 0.41 & 0 & 0.55 & 512 \\
\hline Distance from capital & 0.01 & 0.53 & 1 & 0.01 & 0.84 & 1 & 512 \\
\hline Literacy rate & 0.17 & 0 & 1 & 0.17 & 0 & 1 & 512 \\
\hline Publishing & -22.84 & 0.16 & 0 & -15.82 & 0.58 & 0 & 512 \\
\hline
\end{tabular}


Appendix I. 117 important innovations, 1700-1849

\begin{tabular}{|c|c|c|c|}
\hline Country & $1700-1749$ & $1750-1799$ & $1800-1849$ \\
\hline Denmark & & & $\begin{array}{l}\text { Galvanometer (Oersted, } \\
\text { 1819; Copenhagen) }\end{array}$ \\
\hline \multirow[t]{15}{*}{ France } & \multirow{15}{*}{$\begin{array}{l}\text { Loom coded with } \\
\text { perforated paper } \\
\text { (Bouchon, 1725; } \\
\text { Lyon) } \\
\text { Loom coded with } \\
\text { punched cards } \\
\text { (Falcon, 1728; Lyon) }\end{array}$} & $\begin{array}{l}\text { Steam-powered wagon } \\
\quad \text { (Cugnot, 1770; Paris) } \\
\text { Automatic loom (Vaucanson, } \\
\text { 1775; Paris) }\end{array}$ & $\begin{array}{l}\frac{\text { Automatic loom with }}{\text { perforated cards }} \\
\text { (Jacquard, Breton, 1805; } \\
\text { Lyon) }\end{array}$ \\
\hline & & $\frac{\text { Single-action press }}{\text { Prudon, } 1781 ; \text { Paris) }}$ & $\begin{array}{l}\text { Wet spinning for flax (de } \\
\text { Girard, 1815; Avignon) }\end{array}$ \\
\hline & & \multirow{2}{*}{$\begin{array}{l}\text { Two-engine steamboat } \\
\text { (Jouffroy d'Abbans, 1783; } \\
\text { Lyon) }\end{array}$} & $\frac{\text { Electromagnet (Arago, }}{\text { Ampère, } 1820 ; \text { Paris) }}$ \\
\hline & & & $\begin{array}{r}\text { Water turbine (Burdin, } \\
\text { 1824; Saint-Étienne) }\end{array}$ \\
\hline & & $\begin{array}{l}\text { Hot-air balloon (Montgolfier, } \\
\text { 1783; Paris) }\end{array}$ & $\begin{array}{l}\text { Single-helix propeller } \\
\text { (Sauvage, 1832; Le }\end{array}$ \\
\hline & & $\begin{array}{l}\text { Parachute (Lenormand, 1783; } \\
\text { Montpellier) }\end{array}$ & Havre) \\
\hline & & $\begin{array}{l}\text { Press for the blind (Haüy, } \\
\text { 1784; Paris) }\end{array}$ & $\begin{array}{l}\text { Three-color textile printing } \\
\text { machine (Perrot, 1832; } \\
\text { Rouen) }\end{array}$ \\
\hline & & $\begin{array}{l}\text { Chlorine as bleaching agent } \\
\text { (Berthollet, 1785; Paris) }\end{array}$ & \multirow{6}{*}{$\begin{array}{l}\text { Water turbine with } \\
\text { adjustable vanes } \\
\text { (Fourneyron, 1837; } \\
\text { Besançon) } \\
\text { Photography (Daguerre, } \\
\text { Niepce, 1838; Paris) } \\
\text { Multiple-phase combing } \\
\text { machine (Heilmann, } \\
\text { 1845; Mulhouse) }\end{array}$} \\
\hline & & $\frac{\text { Sodium carbonate from salt }}{\text { (Leblanc, d'Arcet, } 1790 ;}$ & \\
\hline & & Paris) & \\
\hline & & Visual telegraph (Chappe, & \\
\hline & & 1793; Paris) & \\
\hline & & $\begin{array}{l}\text { Vacuum sealing (Appert, } \\
\text { 1795; Paris) }\end{array}$ & \\
\hline & & \multicolumn{2}{|l|}{$\frac{\text { Paper-making machine }}{\text { (Robert, Didot, } 1798 ; \text { Paris) }}$} \\
\hline & & $\begin{array}{l}\text { Illuminating gas from wood } \\
\text { (Lebon, 1799; Paris) }\end{array}$ & \\
\hline
\end{tabular}




$\begin{array}{llc}\text { Germany } & \begin{array}{l}\text { Porcelain } \\ \text { (Tschirnhaus, 1707; } \\ \text { Dresden) }\end{array} & \begin{array}{c}\text { Lithography (Senefelder, } \\ \text { 1796; Munich) }\end{array}\end{array}$

Great Seed drill (Tull, 1701; Crucible steel (Huntsman, Britain Oxford)

Iron smelting with coke (Darby, Thomas, 1709; Birmingham)

Atmospheric engine (Newcomen, Calley, 1712;

Birmingham)

Pottery made with flint (Astbury, 1720; Birmingham)

Quadrant (Hadley, 1731; London)

Flying shuttle (Kay, 1733; Manchester)

Glass-chamber process for sulfuric acid (Ward, White, D'Osterman, 1736; London)

Spinning machine with rollers (Wyatt, Paul, 1738;

Birmingham)

Stereotyping (Ged, 1739; Edingurgh)

Lead-chamber process for sulfuric acid

$$
\text { 1750; York) }
$$

Rib knitting attachment

(Strutt, Roper, 1755;

Birmingham)

Achromatic refracting telescope (Dollond, 1757; London)

Breast wheel (Smeaton, 1759; York)

Bimetallic strip chronometer (Harrison, 1760; London)

Spinning jenny (Hargreaves, 1764; Manchester)

Creamware pottery (Wedgewood, Wieldon, 1765; Birmingham)

Cast-iron railroad (Reynolds, 1768; Birmingham)

Engine using expansive steam operation (Watt, Roebuck, 1769; Glasgow)

Water frame (Arkwright, Kay, 1769; Birmingham)

Efficient atmospheric steam engine (Smeaton, 1772; Newcastle)

Dividing machine (Ramsden, 1773; London)
Machines for tackle block production (M. I. Brunel, Maudslay, 1800; London)

Illuminating gas from coal (Murdock, Boaze, 1802; Birmingham)

Steam locomotive (Trevithick, Homfray, 1804; Plymouth)

Compound steam engine (Woolf, Edwards, 1805; London)

Winding mechanism for loom (Radcliffe, 1805; Manchester)

Arc lamp (Davy, 1808; London)

Food canning (Durand, Girard, 1810; London)

Rack locomotive (Blenkinsop, Murray, 1811; Bradford)

Mechanical printing press (Koenig, Bauer, Bensley, 1811; London)

Steam locomotive on flanged rails (G. Stephenson, Wood, 1814; Newcastle) 


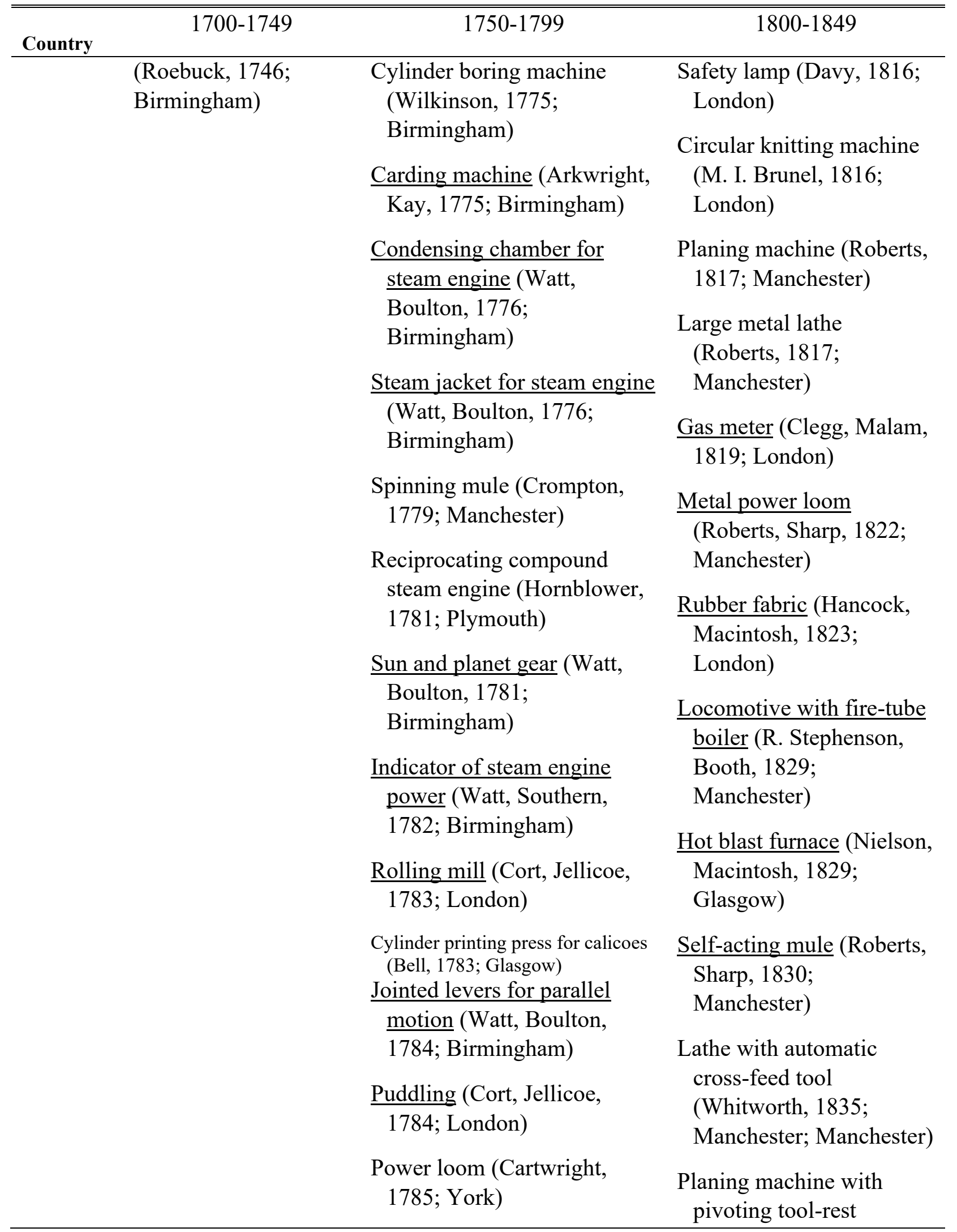




\begin{tabular}{|c|c|c|c|}
\hline Country & $1700-1749$ & $1750-1799$ & $1800-1849$ \\
\hline & & $\begin{array}{l}\text { Speed governor (Watt, } \\
\text { Boulton, 1787; }\end{array}$ & $\begin{array}{l}\text { (Whitworth, 1835; } \\
\text { Manchester) }\end{array}$ \\
\hline & & Birmingham) & Even-current electric cell \\
\hline & & Double-acting steam engine & (Daniell, 1836: London) \\
\hline & & $\begin{array}{l}\text { (Watt, Boulton, 1787; } \\
\text { Birmingham) }\end{array}$ & $\frac{\text { Electric telegraph }}{\text { Wheatstone, } 1837}$ \\
\hline & & Threshing machine (Meikle, & London) \\
\hline & & 1788; Edinburgh) & $\underline{\text { Riveting machine }}$ \\
\hline & & $\begin{array}{l}\text { Single-phase combing } \\
\text { machine (Cartwright, 1789; }\end{array}$ & $\begin{array}{l}\text { (Fairbairn, Smith, 1838; } \\
\text { Manchester) }\end{array}$ \\
\hline & & (OKK) & Transatlantic steamer (I. \\
\hline & & $\frac{\text { Machines for lock production }}{\text { (Bramah, Maudslay, } 1790 ;}$ & $\begin{array}{l}\text { K. Brunel, Guppy, 1838; } \\
\text { Bristol) }\end{array}$ \\
\hline & & London) & Assembly-line production \\
\hline & & Single-action metal printing & (Bodmer, 1839; \\
\hline & & press (Stanhope, Walker, & Manchester) \\
\hline & & 1795; London) & Multiple-blade propeller \\
\hline & & $\begin{array}{l}\text { Hydraulic press (Bramah, } \\
\text { Maudslay, 1796; London) }\end{array}$ & $\begin{array}{l}\text { (Smith, Pilgrim, 1839; } \\
\text { London) }\end{array}$ \\
\hline & & $\begin{array}{l}\text { High-pressure steam engine } \\
\text { (Trevithick, Murdoch, } \\
\text { 1797; Plymouth) }\end{array}$ & $\begin{array}{l}\text { Steam hammer (Nasmyth, } \\
\text { Gaskell, 1842; } \\
\text { Manchester) }\end{array}$ \\
\hline & & $\begin{array}{l}\text { Slide lathe (Maudslay, 1799; } \\
\text { London) }\end{array}$ & $\frac{\text { Iron, propellor-driven }}{\underline{\text { steamship }(\mathrm{I} . \mathrm{K} . \text { Brunel, }}}$ \\
\hline & & & $\begin{array}{l}\text { Measuring machine (Whit- } \\
\text { worth, 1845; } \\
\text { Manchester) }\end{array}$ \\
\hline & & & $\begin{array}{l}\text { Multiple-spindle drilling } \\
\text { machine (Roberts, 1847; } \\
\text { Manchester) }\end{array}$ \\
\hline Italy & & & $\begin{array}{l}\text { Electric battery (Volta, } \\
\text { 1800; Como) }\end{array}$ \\
\hline
\end{tabular}




\begin{tabular}{|c|c|c|c|}
\hline Country & 1700-1749 & $1750-1799$ & $1800-1849$ \\
\hline $\begin{array}{l}\text { Switzer- } \\
\text { land }\end{array}$ & & $\begin{array}{l}\text { Massive platen printing press } \\
\text { (Haas, 1772; Basel) } \\
\text { Stirring process for glass } \\
\text { (Guinand, 1796; Berne) }\end{array}$ & \\
\hline \multirow[t]{8}{*}{$\begin{array}{l}\text { United } \\
\text { States }\end{array}$} & & $\begin{array}{l}\text { Continuous-flow production } \\
\text { (Evans, Ellicott, 1784; } \\
\text { Philadelphia) }\end{array}$ & $\begin{array}{l}\text { Single-engine steamboat } \\
\text { (Fulton, Livingston, } \\
\text { 1807) }\end{array}$ \\
\hline & & $\frac{\text { Cotton gin (Whitney, Green, }}{1793 ; \text { Philadelphia) }}$ & $\begin{array}{l}\text { Milling machine (North, } \\
\text { 1818; New York) }\end{array}$ \\
\hline & & $\begin{array}{l}\text { Machine to cut and head nails } \\
\text { (Perkins, 1795; Boston) }\end{array}$ & $\begin{array}{l}\frac{\text { Interchangeable parts }}{\text { (North, Hall, 1824; New }} \\
\text { York) }\end{array}$ \\
\hline & & & $\begin{array}{l}\text { Ring spinning machine } \\
\text { (Thorp, Jencks, 1828; } \\
\text { Boston) }\end{array}$ \\
\hline & & & $\begin{array}{l}\text { Grain reaper }(\text { McCormick, } \\
\text { Anderson, 1832; } \\
\text { Philadelphia) }\end{array}$ \\
\hline & & & $\begin{array}{l}\text { Binary-code telegraph } \\
\text { (Morse, Vail, 1845; New } \\
\text { York) }\end{array}$ \\
\hline & & & $\frac{\text { Sewing machine (Howe, }}{\text { Fisher, } 1846 ; \text { Boston) }}$ \\
\hline & & & $\begin{array}{l}\text { Rotary printing press } \\
\text { (Hoe, 1847; New York) }\end{array}$ \\
\hline
\end{tabular}

Sources: see Section 2(a) of text. 
Appendix II. Year of first monolingual dictionary

\begin{tabular}{|c|c|c|c|}
\hline Country & Year & Author(s) & Publication \\
\hline Austria & 1868 & Otto Back et. al. & Österreichisches Wörterbuch \\
\hline Belgium (French) & 1680 & & Same as France (north) \\
\hline Belgium (Flem.) & 1864 & & Same as Netherlands \\
\hline Denmark & 1833 & Christian Molbech & Dansk Ordbog \\
\hline England & 1658 & Edward Phillips & $\begin{array}{l}\text { The New World of English } \\
\text { Words }\end{array}$ \\
\hline France (north) & 1680 & Pierre Richelet & Dictionnaire français \\
\hline France (south) & 1815 & & Standardization delayed ${ }^{\mathrm{a}}$ \\
\hline Germany & 1786 & $\begin{array}{l}\text { Johann Christoph } \\
\text { Adelung }\end{array}$ & $\begin{array}{l}\text { Grammatich-kritisches } \\
\text { Wörterbuch der hochdeutschen } \\
\text { Mundart }\end{array}$ \\
\hline Ireland & 1658 & & Same as England \\
\hline Italy & 1897 & $\begin{array}{l}\text { Emilio Broglio \& } \\
\text { Giovan Battista } \\
\text { Giorgini }\end{array}$ & $\begin{array}{l}\text { Nòvo vocabolario della lingua } \\
\text { italiana secondo l'uso di } \\
\text { Firenze }\end{array}$ \\
\hline Netherlands & 1864 & $\begin{array}{l}\text { Marcus and Nathan } \\
\text { Solomon Calisch }\end{array}$ & $\begin{array}{l}\text { Nieuw Woordenboek der } \\
\text { Nederlandsche Taal }\end{array}$ \\
\hline Scotland & 1658 & & Same as England ${ }^{b}$ \\
\hline Switzerland (Fr.) & 1680 & & Same as France (north) \\
\hline $\begin{array}{l}\text { Switzerland } \\
\text { (German) }\end{array}$ & 1786 & & Same as Germany \\
\hline United States & 1658 & & Same as England \\
\hline
\end{tabular}

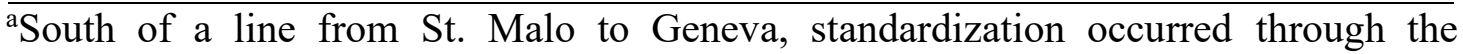
integrating effects of the revolutionary and Napoleonic Wars (Graff, 1991, 193).

bIn 1611, King James I sponsored a new English translation of the Bible and ordered that this "Authorized Version" be used throughout his Scottish Kingdom (Crystal, 2003, p. 53).

Note: Other early dictionaries fail to reflect the existence of a standardized written vernacular. Robert Cawdrey's Table Alphabeticall (1604) was a list of hard words to spell. Josua Maaler's, Die Teütsch Spraach (1561) was devoted to Swiss and Upper German vocabulary. Kornelius Kiliaan's (1599) Etymologicum used Latin to explain Dutch words, as did Jean Nicot's (1606) Trésor de la langue françoise for the French language. As for Italy, the Accademia della Crusca's Vocabolario of the Florentine vulgar tongue (1612) and Sebastián de Covarrubias' El Tesoro de la lengua castellana $o$ Española and had only a slight effect on spoken Italian and Spanish respectively; see section 2(c) in the text. 
Appendix III. Summary statistics

\begin{tabular}{lrrrrrr}
\hline & & & & Standard & & \\
& & & & & \\
All innovations & $1700-1749$ & 13 & 0.05 & 0.38 & 5 & 0 \\
& $1750-1799$ & 53 & 0.21 & 1.19 & 13 & 0 \\
& $1800-1849$ & 51 & 0.20 & 1.18 & 13 & 0 \\
Cooperative & Total & 117 & 0.47 & 2.28 & 21 & 0 \\
innovations & & & & & & \\
& $1700-1749$ & 4 & 0.02 & 0.20 & 3 & 0 \\
& $1750-1799$ & 23 & 0.09 & 0.77 & 11 & 0 \\
Non-cooperative & $1800-1849$ & 27 & 0.11 & 0.63 & 8 & 0 \\
innovations & Total & 54 & 0.22 & 1.32 & 15 & 0 \\
& $1700-1749$ & 9 & 0.04 & 0.23 & 2 & 0 \\
& $1750-1799$ & 30 & 0.12 & 0.62 & 7 & 0 \\
City population & $1800-1849$ & 24 & 0.10 & 0.66 & 9 & 0 \\
& Total & 63 & 0.25 & 1.19 & 13 & 0 \\
Population change & 1700 & & 21 & 51 & 575 & 6 \\
\hline
\end{tabular}

Sources: See "Data Sources" at the end of the text. 